\title{
Lacinutrix algicola sp. nov. and Lacinutrix mariniflava sp. nov., two novel marine alga- associated bacteria and emended description of the genus Lacinutrix
}

Correspondence

Sang-Jin Kim

s-jkim@kordi.re.kr

\author{
Olga I. Nedashkovskaya, ${ }^{1,2}$ Kae Kyoung Kwon, ${ }^{1}$ Sung-Hyun Yang, ${ }^{1}$ \\ Hee-Soon Lee, ${ }^{1}$ Kyung Ho Chung $^{3}$ and Sang-Jin Kim ${ }^{1}$ \\ ${ }^{1}$ Marine Biotechnology Research Center, Korea Ocean Research and Development Institute, PO \\ Box 29, Ansan 425-600, Republic of Korea \\ ${ }^{2}$ Pacific Institute of Bioorganic Chemistry of the Far-Eastern Branch of the Russian Academy of \\ Sciences, Pr. 100 Let Vladivostoku 159, 690022 Vladivostok, Russia \\ ${ }^{3}$ Korea Polar Research Institute, Korea Ocean Research and Development Institute, Songdo \\ Technopark 7-50, Incheon PO Box 32, 406-840, Republic of Korea
}

Two heterotrophic, aerobic, yellow-pigmented, Gram-negative, non-gliding bacteria, designated $A K S 293^{\top}$ and $A K S 432^{\top}$, isolated from a red alga, were analysed using a polyphasic taxonomic approach. 16S rRNA gene sequence analysis revealed that the novel strains were affiliated to the genus Lacinutrix, a member of the family Flavobacteriaceae, showing sequence similarities of 96.1-96.4\% with respect to the type strain of Lacinutrix copepodicola. The two novel isolates shared $99.5 \% 16 \mathrm{~S}$ rRNA gene sequence similarity and 55.0\% DNA-DNA relatedness. They grew optimally at $17.5{ }^{\circ} \mathrm{C}$ and $\mathrm{pH}$ 6.5. The main cellular fatty acids of strain $A K S 293^{\top}$ were iso-

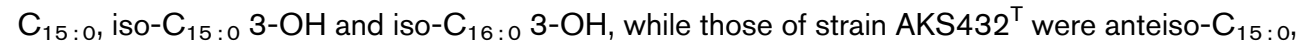
iso- $\mathrm{C}_{15: 0}$, iso- $\mathrm{C}_{15: 1}$ and iso- $\mathrm{C}_{15: 0} 3-\mathrm{OH}$. In both cases, the major isoprenoid quinone was MK6. The DNA G+C contents were 34.7 and 37.0 mol\% for strains $\mathrm{AKS}_{29}{ }^{\top}$ and $\mathrm{AKS} 432^{\top}$, respectively. The phylogenetic evidence, phenotypic data and DNA-DNA hybridization results support the differentiation of strains $A K S 293^{\top}$ and $A K S 432^{\top}$ from each other and from their closest relative, L. copepodicola DJ3 ${ }^{\top}$. Therefore, strains $A K S 293^{\top}$ and $A K S 432^{\top}$ represent two novel species, for which the names Lacinutrix algicola sp. nov. and Lacinutrix mariniflava sp. nov. are proposed, respectively. The type strain of $L$. algicola sp. nov. is $\mathrm{AKS}_{293}{ }^{\top}(=\mathrm{KCCM}$ $42313^{\top}=\mathrm{JCM} 13825^{\top}$ ) and the type strain of $L$. mariniflava sp. nov. is AKS432 ${ }^{\top}(=\mathrm{KCCM}$ $42306^{\top}=\mathrm{JCM} 13824^{\top}$ ). An emended description of the genus Lacinutrix is also proposed.
The genus Lacinutrix was created by Bowman \& Nichols (2005), within the family Flavobacteriaceae (Bernardet et al., 2002), to accommodate Gram-negative, heterotrophic, aerobic, non-gliding, yellow-pigmented bacteria. A single strain, Lacinutrix copepodicola $\mathrm{DJ} 3^{\mathrm{T}}$ was isolated from a calanoid copepod, Paralabidocera antarctica, collected from a meromictic Antarctic lake (Bowman \& Nichols, 2005). The genera Olleya (Nichols et al., 2005) and Mesoflavibacter (Asker et al., 2007) are the closest phylogenetic neighbours of the genus Lacinutrix (Fig. 1).

During a survey of the microbial diversity of Antarctic marine environments, two novel bacterial strains, designated

The GenBank/EMBL/DDBJ accession numbers for the 16S rRNA gene sequences of strains $\mathrm{AKS}_{2} 93^{\top}$ and $\mathrm{AKS}^{\mathrm{N}} 32^{\top}$ are $\mathrm{DQ} 167238$ and DQ167239, respectively.
AKS293 ${ }^{\mathrm{T}}$ and AKS432 ${ }^{\mathrm{T}}$, were isolated from alga and studied using a polyphasic taxonomic approach. On the basis of the results of this study, two novel species of the genus Lacinutrix are proposed.

Strains AKS293 ${ }^{\mathrm{T}}$ and $\mathrm{AKS} 432^{\mathrm{T}}$ were isolated from a red alga belonging to the family Gigartinaceae, growing in the subtidal zone of Marian Cove, King George Island, Antarctica. For strain isolation, a small piece of algal frond was ground, diluted with sterile seawater and spread on marine agar 2216 (Difco). Inoculated plates were cultivated at $4{ }^{\circ} \mathrm{C}\left(\mathrm{AKS} 432^{\mathrm{T}}\right)$ or at $25^{\circ} \mathrm{C}\left(\mathrm{AKS} 293^{\mathrm{T}}\right)$ for 1 week. After primary isolation and purification, strains were cultivated at $15{ }^{\circ} \mathrm{C}$ on the same medium and stored at $-80{ }^{\circ} \mathrm{C}$ in marine broth (Difco) supplemented with $20 \%$ (v/v) glycerol.

The 16S rRNA gene was amplified by means of direct PCR and then sequenced using an ABI 3100 automatic DNA 


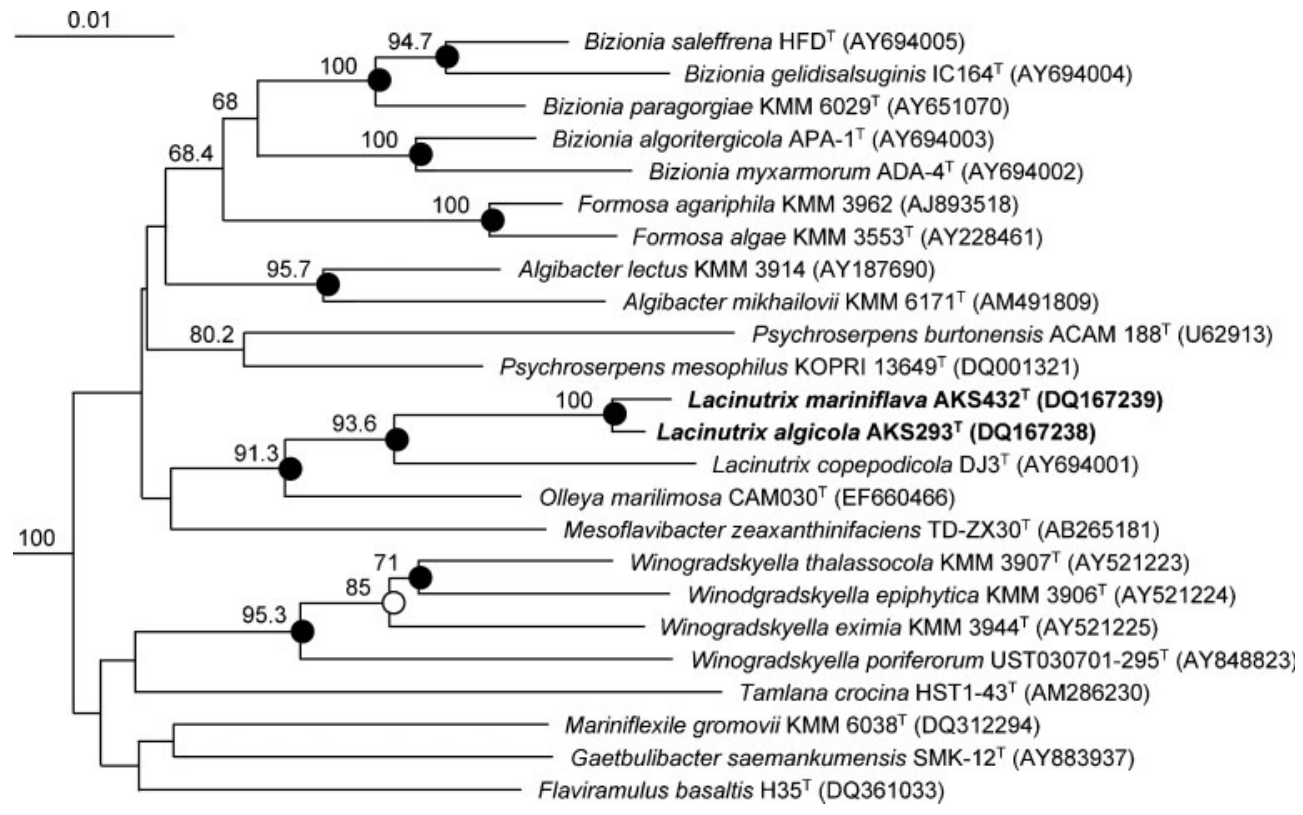

Fig. 1. Rooted neighbour-joining phylogenetic tree, based on almost-complete 16S rRNA gene sequences (1294 unambiguously aligned bp) showing the relationships between strains $A K S 293^{\top}$ and $A K S 432^{\top}$ and closely related members of the family Flavobacteriaceae. The 16S rRNA gene sequences of Bacteroides fragilis ATCC $25285^{\top}$ (NC003228) and Sphingobacterium spiritivorum DSM $2582^{\top}$ (AJ459411) served as outgroups (not shown). Bootstrap values greater than $50 \%$ (based on 1000 replicates) are shown at nodes. Nodes with bootstrap values greater than $50 \%$ (open circles) or greater than $70 \%$ (filled circles) recovered in a maximum-parsimony tree based on distances calculated by the maximum-likelihood method are indicated. Bar, 0.01 nucleotide substitutions per nucleotide position.

sequencer $(\mathrm{ABI})$ according to the manufacturer's instructions. Comparisons of the 16S rRNA gene sequence with sequences retrieved from GenBank and phylogenetic analyses were conducted according to the procedure described by Kwon et al. (2005).

Phylogenetic analysis of the almost-complete $16 \mathrm{~S}$ rRNA gene sequences of strains AKS293 ${ }^{\mathrm{T}}$ and $\mathrm{AKS} 432^{\mathrm{T}}(1294 \mathrm{nt}$ in each case) revealed that the strains formed a distinct lineage in the vicinity of $L$. copepodicola $\mathrm{DJ} 3^{\mathrm{T}}$, sharing $96.1-$ $96.4 \%$ sequence similarity with this strain and $99.5 \%$ sequence similarity with each other (Fig. 1). DNA was isolated according to the procedure described by Marmur (1961) and the DNA relatedness between the two isolates was measured fluorometrically by using the microplate hybridization method described by Ezaki et al. (1989). The strains shared $55.0 \%$ DNA relatedness, a value that is well below the threshold accepted for species delineation (Wayne et al., 1987). Thus, strains $\mathrm{AKS}_{2} 93^{\mathrm{T}}$ and AKS432 ${ }^{\mathrm{T}}$ represent two different species.

DNA G + C contents were analysed by using HPLC with a symmetry reversed-phase C18 column (Stackebrandt \& Liesack, 1993); the values for strains $\mathrm{AKS}_{2} 93^{\mathrm{T}}$ and AKS $432^{\mathrm{T}}$ were 37.0 and $34.7 \mathrm{~mol} \%$, respectively.

Analysis of fatty acid methyl esters was carried out by using the MIDI/Hewlett Packard Microbial Identification System (MIS; Sasser, 1990), according to the manufacturer's instructions, on cells grown on marine agar 2216 for 3 days at $25{ }^{\circ} \mathrm{C}$. The predominant fatty acids of strain AKS293 ${ }^{\mathrm{T}}$ were $\mathrm{C}_{15: 0}(6.7 \%)$, iso- $\mathrm{C}_{15: 0}(12.5 \%)$, iso- $\mathrm{C}_{15: 1}$ (7.2\%), iso- $\mathrm{C}_{16: 1}(7.2 \%)$, iso- $\mathrm{C}_{15: 0} 3-\mathrm{OH}(10.0 \%)$, iso$\mathrm{C}_{16: 0} 3-\mathrm{OH}(14.4 \%)$ and summed feature $3(9.2 \%)$ and those of strain $\mathrm{AKS} 432^{\mathrm{T}}$ were iso- $\mathrm{C}_{15: 0}(10.6 \%)$, anteiso$\mathrm{C}_{15: 0}(12.5 \%)$, iso- $\mathrm{C}_{15: 1}(11.6 \%)$, anteiso- $\mathrm{C}_{15: 1}(7.5 \%)$, iso- $\mathrm{C}_{15: 0} 3-\mathrm{OH}(12.2 \%)$, iso- $\mathrm{C}_{16: 0} 3-\mathrm{OH}(8.9 \%)$, iso$\mathrm{C}_{17: 0} 3-\mathrm{OH}(7.6 \%)$ and summed feature $3(5.8 \%)$ (Table 1). Despite the existence of differences in culture conditions and analytical methods, the two novel isolates and L. copepodicola $\mathrm{DJ} 3^{\mathrm{T}}$ contained large amounts of isobranched $\mathrm{C}_{15}$ fatty acids. However, significant differences in fatty acid composition and in the proportion of some components were identified between the two isolates (Table 1). Isoprenoid quinones were extracted from lyophilized cells and analysed according to the procedure described by Collins (1985). The major respiratory quinone was MK-6 in both isolates. The chemotaxonomic data obtained in this study were in accordance with the characteristics of members of the family Flavobacteriaceae (Bernardet et al., 2002).

Unless otherwise stated, phenotypic analysis of strains $\mathrm{AKS} 293^{\mathrm{T}}$ and $\mathrm{AKS} 432^{\mathrm{T}}$ was performed according to the minimal standards for describing new taxa in the family Flavobacteriaceae proposed by Bernardet et al. (2002) and by using previously described methods (Bae et al., 2005, 
Table 1. Fatty acid profiles (\%) of strain $\mathrm{AKS} 293^{\top}$, strain AKS $432^{\top}$ and L. copepodicola DJ3 ${ }^{\top}$

Strains: $1, \mathrm{AKS}_{2} 93^{\mathrm{T}} ; 2, \mathrm{AKS} 432^{\mathrm{T}} ; 3$, L. copepodicola $\mathrm{DJ} 3^{\mathrm{T}}$. Data are from Bowman \& Nichols (2005) and this study. Fatty acids amounting to $<0.5 \%$ of the total fatty acids in all strains were omitted. tr, Trace $(<1 \%)$; Br, branched fatty acid but branching position is unclear. The culture conditions and analytical procedures used for isolates AKS293 ${ }^{\mathrm{T}}$ and $\mathrm{AKS} 432^{\mathrm{T}}$ differed from those used for L. copepodicola $\mathrm{DJ} 3^{\mathrm{T}}$.

\begin{tabular}{|c|c|c|c|}
\hline Fatty acid & 1 & 2 & 3 \\
\hline \multicolumn{4}{|l|}{ Straight-chain } \\
\hline $\mathrm{C}_{14: 0}$ & $\operatorname{tr}$ & $\operatorname{tr}$ & $\operatorname{tr}$ \\
\hline $\mathrm{C}_{15: 0}$ & 6.7 & 1.6 & 3.7 \\
\hline $\mathrm{C}_{16: 0}$ & 1.0 & $\operatorname{tr}$ & 2.9 \\
\hline \multicolumn{4}{|l|}{ Branched } \\
\hline iso- $\mathrm{C}_{14: 0}$ & 4.1 & $\operatorname{tr}$ & 1.4 \\
\hline iso- $\mathrm{C}_{15: 0}$ & 12.5 & 10.6 & 19.9 \\
\hline anteiso- $\mathrm{C}_{15: 0}$ & 4.6 & 12.5 & 18.2 \\
\hline iso- $\mathrm{C}_{16: 0}$ & 3.4 & 2.2 & 7.1 \\
\hline \multicolumn{4}{|l|}{ Unsaturated } \\
\hline $\mathrm{C}_{15: 1} \omega 6 c$ & 2.7 & 1.4 & 1.2 \\
\hline $\mathrm{C}_{17: 1} \omega 6 c$ & 1.8 & $\operatorname{tr}$ & \\
\hline $\mathrm{C}_{17: 1} \omega 8 c$ & $\operatorname{tr}$ & & \\
\hline $\mathrm{C}_{18: 1} \omega 5 c$ & & $\operatorname{tr}$ & \\
\hline Br- $\mathrm{C}_{14: 1}$ & & & $\operatorname{tr}$ \\
\hline iso- $\mathrm{C}_{15: 1}$ & 7.2 & 11.6 & 12.0 \\
\hline anteiso- $\mathrm{C}_{15: 1}$ & 1.2 & 7.5 & 14.2 \\
\hline $\mathrm{Br}-\mathrm{C}_{16: 1}$ & 7.2 & 3.1 & 4.6 \\
\hline iso- $\mathrm{C}_{17: 1} \omega 9 c$ & 1.1 & 1.3 & - \\
\hline anteiso- $\mathrm{C}_{17: 1} \omega 9 c$ & & 1.6 & \\
\hline \multicolumn{4}{|l|}{ Hydroxy } \\
\hline $\mathrm{C}_{15: 0} 2-\mathrm{OH}$ & 1.9 & 2.5 & \\
\hline $\mathrm{C}_{15: 0} 3-\mathrm{OH}$ & 1.1 & & $\operatorname{tr}$ \\
\hline $\mathrm{C}_{16: 0} 3-\mathrm{OH}$ & $\operatorname{tr}$ & $\operatorname{tr}$ & \\
\hline $\mathrm{C}_{17: 0} 2-\mathrm{OH}$ & $\operatorname{tr}$ & 3.9 & \\
\hline iso- $\mathrm{C}_{14: 0} 3-\mathrm{OH}$ & 1.0 & & \\
\hline iso- $\mathrm{C}_{15: 0} 3-\mathrm{OH}$ & 10.0 & 12.2 & 3.1 \\
\hline anteiso- $\mathrm{C}_{15: 0} 3-\mathrm{OH}$ & & & 2.1 \\
\hline iso- $\mathrm{C}_{16: 0} 3-\mathrm{OH}$ & 14.4 & 8.9 & 2.7 \\
\hline iso- $\mathrm{C}_{17: 0} 3-\mathrm{OH}$ & 3.6 & 7.6 & 2.3 \\
\hline anteiso- $\mathrm{C}_{17: 0} 3-\mathrm{OH}$ & & & 1.7 \\
\hline Summed feature $3^{\star}$ & 9.2 & 5.8 & 2.8 \\
\hline
\end{tabular}

* Summed features represent fatty acids that could not be separated by GLC with the MIDI system; summed feature 3 comprises iso- $\mathrm{C}_{15: 0}$ 2-OH and/or $\mathrm{C}_{16: 1} \omega 7 c$.

2007; Sohn et al., 2004). Scanning electron micrographs were taken using a JSM-2000EXII (JEOL) electron microscope after bacterial cells had been dehydrated using a graded series of ethanol dilutions. The bacterial suspensions used to inoculate API 20E, API 20NE (bioMérieux) and Microlog GN2 (Biolog) systems were prepared in $2 \%$ sea salts (Sigma) solution. The tolerance range for $\mathrm{NaCl}$ was tested in marine broth prepared with distilled water and supplemented with $0-7 \% \mathrm{NaCl}(\mathrm{w} / \mathrm{v})$.
The physiological, biochemical and morphological characteristics of the two strains are given in the species descriptions and those that serve to differentiate the two isolates from each other and from L. copepodicola $\mathrm{DJ} 3^{\mathrm{T}}$ are listed in Table 2.

The results of the 16S rRNA-based phylogenetic analysis taken together with the phenotypic findings (Table 2) allow the affiliation of strains $\mathrm{AKS} 293^{\mathrm{T}}$ and $\mathrm{AKS} 432^{\mathrm{T}}$ to the genus Lacinutrix and their classification as two separate species, for which the names Lacinutrix algicola sp. nov. and Lacinutrix mariniflava sp. nov. are proposed, respectively. Additional data are included in an emended description of the genus Lacinutrix.

\section{Emended description of the genus Lacinutrix Bowman and Nichols 2005}

The description of the genus Lacinutrix is as given by Bowman \& Nichols (2005), with the following amendments. Cells are approximately $0.4-0.8 \mu \mathrm{m}$ wide and $0.7-$ $2.5 \mu \mathrm{m}$ long. The DNA $\mathrm{G}+\mathrm{C}$ content range is $35-$ $37 \mathrm{~mol} \%$.

\section{Description of Lacinutrix algicola sp. nov.}

Lacinutrix algicola [al.gi.co'la. L. fem. n. alga a seaweed; L. suffix - cola (from L. masc. or fem. n. incola) a dweller; N.L. fem. n. algicola an alga dweller].

Cells are Gram-negative, non-gliding, straight or slightly curved rods $0.5-0.6 \mu \mathrm{m}$ wide and $0.7-1.7 \mu \mathrm{m}$ long. On marine agar, colonies are circular, $1-3 \mathrm{~mm}$ in diameter, convex, shiny, butyrous, have entire edges and are yellowpigmented. Flexirubin-type pigments are not formed. Does not form resting cells or spores. Does not require $\mathrm{Na}^{+}$ions for growth. Growth occurs in the presence of up to $2.5 \%$ $\mathrm{NaCl}$, at $0-25{ }^{\circ} \mathrm{C}$ and at $\mathrm{pH} 5.5-8.5$. Optimal growth is observed with $0.5 \% \mathrm{NaCl}$, at $17.5{ }^{\circ} \mathrm{C}$ and at $\mathrm{pH}$ 6.5. Oxidase, catalase, alkaline phosphatase and $\beta$-galactosidase activities are present, but arginine dihydrolase activity is absent. Gelatin and casein are hydrolysed, but aesculin, agar, Tweens 40 and 80 and urea are not hydrolysed. Acid is not produced from D-glucose. In the API 20NE system, arabinose, glucose, mannose, maltose, $\mathrm{N}$-acetylglucosamine, gluconate, caprate, adipate, malate, citrate and phenyl acetate are not utilized. In the Biolog GN2 microplate, the following substrates are utilized: D-arabitol, D-mannitol, D-psicose, methyl pyruvate, D-glucosaminic acid, D-glucuronic acid, $\alpha$-hydroxybutyric acid, $\beta$-hydroxybutyric acid, $\alpha$-ketoglutaric acid, L-glutamic acid and glycyl L-glutamic acid. In the API ZYM system, esterase (C4), esterase lipase (C8), leucine-, valine- and cystine arylamidases, trypsin, $\alpha$-chymotrypsin, acid phosphatase and naphthol-AS-BI-phosphohydrolase activities are present, but lipase (C14), $\alpha$-galactosidase, $\beta$-glucuronidase, $\alpha$ - and $\beta$-glucosidases, $N$-acetyl- $\beta$-glucosaminidase, $\alpha$-mannosidase and $\alpha$-fucosidase activities are absent. Nitrate is not reduced. Indole is not produced. The major fatty acids 


\section{Table 2. Phenotypic properties of Lacinutrix species}

All strains gave positive results in tests for the following properties: respiratory metabolism; catalase, alkaline phosphatase and leucine arylamidase activities and hydrolysis of gelatin. All strains gave negative results in tests for the following properties: gliding motility; arginine dihydrolase, tryptophan deaminase, $\alpha$-galactosidase, $\beta$-glucuronidase, $\alpha$ - and $\beta$-glucosidases, $\alpha$-fucosidase and nitrate reductase activities; flexirubin-type pigments; hydrolysis of agar and urea; acid production from glucose; utilization of arabinose, sucrose, L-alanine, L-histidine, citrate, D-gluconate, adipate, caprate, malate and phenylacetate. Data are from Bowman \& Nichols (2005) and this study.

\begin{tabular}{|c|c|c|c|}
\hline Characteristic & Strain $\mathrm{AKS}_{293}{ }^{\mathrm{T}}$ & Strain AKS432 ${ }^{\mathrm{T}}$ & L. copepodicola $\mathrm{DJ} 3^{\mathrm{T}}$ \\
\hline$N$-Acetyl- $\beta$-D-glucosaminidase & - & - & + \\
\hline Temperature range $\left({ }^{\circ} \mathrm{C}\right)$ & $0-25$ & $0-22$ & $-2-25$ \\
\hline $\mathrm{pH}$ value for growth & $5.5-8.5$ & $6.0-8.5$ & ND \\
\hline \multicolumn{4}{|l|}{ Hydrolysis of: } \\
\hline Casein & + & + & - \\
\hline Tween 40 & - & + & - \\
\hline Tween 80 & - & - & + \\
\hline \multicolumn{4}{|l|}{ Utilization of: } \\
\hline D-Glucose, glycogen, maltose & - & + & + \\
\hline D-Mannose & - & - & + \\
\hline DNA G $+\mathrm{C}$ content $(\mathrm{mol} \%)$ & 37.0 & 34.7 & 37.0 \\
\hline
\end{tabular}

$(>5 \%)$ are $\mathrm{C}_{15: 0}$, iso- $\mathrm{C}_{15: 0}$, iso- $\mathrm{C}_{15: 1}$, branched $\mathrm{C}_{16: 1}$, iso$\mathrm{C}_{15: 0} 3-\mathrm{OH}$, iso- $\mathrm{C}_{16: 0} 3-\mathrm{OH}$ and summed feature 3 . The complete fatty acid composition is given in Table 1.

The type strain, AKS293 ${ }^{\mathrm{T}} \quad\left(=\mathrm{KCCM} \quad 42313^{\mathrm{T}}=\mathrm{JCM}\right.$ $13825^{\mathrm{T}}$ ), was isolated from a marine red alga collected at Marian Cove, King George Island, South Shetland Islands, Antarctica. The DNA G $+\mathrm{C}$ content of the type strain is $37.0 \mathrm{~mol} \%$.

\section{Description of Lacinutrix mariniflava sp. nov.}

Lacinutrix mariniflava (ma.ri.ni.fla'va. L. adj. marinus marine; L. adj. flavus golden yellow; N.L. fem. adj. mariniflava marine and yellow-pigmented).

Cells are Gram-negative, non-gliding, straight or slightly curved rods $0.6-0.8 \mu \mathrm{m}$ wide and $1.1-2.5 \mu \mathrm{m}$ long. On marine agar, colonies are circular, $1-3 \mathrm{~mm}$ in diameter, convex, shiny, butyrous, have entire edges and are yellowpigmented. Flexirubin-type pigments are not formed. Does not form resting cells or spores. Requires $\mathrm{Na}^{+}$ions for growth. Growth occurs in the presence of $0.5-4.5 \% \mathrm{NaCl}$, at $0-22{ }^{\circ} \mathrm{C}$ and at $\mathrm{pH}$ 6.0-8.5. Optimal growth is observed with $2.5 \% \mathrm{NaCl}$, at $17.5{ }^{\circ} \mathrm{C}$ and at $\mathrm{pH}$ 6.5. Oxidase, catalase, alkaline phosphatase and $\beta$-galactosidase activities are present, but arginine dihydrolase activity is absent. Gelatin, aesculin, casein and Tween 40 are hydrolysed, but agar, Tween 80 and urea are not hydrolysed. Acid is not produced from D-glucose. In the API 20NE system, arabinose, glucose, mannose, $\mathrm{N}$-acetylglucosamine, gluconate, caprate, adipate, malate, citrate and phenylacetate are not utilized. In the Biolog GN2 microplate, the following substrates are utilized: dextrin, glycogen, D-galactose, $\alpha$-Dglucose, maltose, D-mannitol, L-aspartic acid and Lglutamic acid. In the API ZYM system, esterase (C4), esterase lipase (C8), leucine-, valine- and cystine arylamidases, trypsin, $\alpha$-chymotrypsin, acid phosphatase and naphthol-AS-BI-phosphohydrolase activities are present, but lipase (C14), $\alpha$-galactosidase, $\beta$-glucuronidase, $\alpha$ - and $\beta$-glucosidases, $N$-acetyl- $\beta$-glucosaminidase, $\alpha$-mannosidase and $\alpha$-fucosidase are absent. Nitrate is not reduced. Indole is not produced. The major fatty acids $(>5 \%)$ are iso- $\mathrm{C}_{15: 0}$, anteiso- $\mathrm{C}_{15: 0}$, iso- $\mathrm{C}_{15: 1}$, anteiso- $\mathrm{C}_{15: 1}$, iso- $\mathrm{C}_{15: 0}$ $3-\mathrm{OH}$, iso- $\mathrm{C}_{16: 0} 3-\mathrm{OH}$, iso- $\mathrm{C}_{17: 0} 3-\mathrm{OH}$ and summed feature 3. The complete fatty acid composition is given in Table 1.

The type strain, AKS432 $2^{\mathrm{T}} \quad\left(=\mathrm{KCCM} \quad 42306^{\mathrm{T}}=\mathrm{JCM}\right.$ $13824^{\mathrm{T}}$ ), was isolated from a marine red alga collected at Marian Cove, King George Island, South Shetland Islands, Antarctica. The DNA G+C content of the type strain is $34.7 \mathrm{~mol} \%$.

\section{Acknowledgements}

This work was supported by the Marine and Extreme Genome Research Center Program of the Ministry of Land, Transport and Maritime Affairs, Korea, Monitoring on Environmental Changes at 
the Korean Arctic and Antarctic Stations (PE08040), funded by the Korea Polar Research Institute of the Korea Ocean Research and Development Institute and the International Fellowship Program of KRF (to O.I. N.), Korea. We thank members of the Korea Polar Research Institute for facilitating sample collection and pretreatment.

\section{References}

Asker, D., Beppu, T. \& Ueda, K. (2007). Mesoflavibacter zeaxanthinifaciens gen. nov., sp. nov., a novel zeaxanthin-producing marine bacterium of the family Flavobacteriaceae. Syst Appl Microbiol 30, 291-296.

Bae, S. S., Lee, J.-H. \& Kim, S.-J. (2005). Bacillus alveayuensis sp. nov., a thermophilic bacterium isolated from deep-sea sediments of the Ayu Trough. Int J Syst Evol Microbiol 55, 1211-1215.

Bae, S. S., Kwon, K. K., Yang, S.-H., Lee, H.-S., Kim, S.-J. \& Lee, J. H. (2007). Flagellimonas eckloniae gen. nov., sp. nov., a mesophilic marine bacterium of the family Flavobacteriaceae, isolated from the rhizosphere of Ecklonia kurome. Int J Syst Evol Microbiol 57, 10501054.

Bernardet, J.-F., Nakagawa, Y. \& Holmes, B. (2002). Proposed minimal standards for describing new taxa of the family Flavobacteriaceae and emended description of the family. Int J Syst Evol Microbiol 52, 1049-1070.

Bowman, J. P. \& Nichols, D. S. (2005). Novel members of the family Flavobacteriaceae from Antarctic maritime habitats including Subsaximicrobium wynnwilliamsii gen. nov., sp. nov., Subsaximicrobium saxinquilinus sp. nov., Subsaxibacter broadyi gen. nov., sp. nov., Lacinutrix copepodicola gen. nov., sp. nov., and novel species of the genera Bizionia, Gelidibacter and Gillisia. Int J Syst Evol Microbiol 55, 1471-1486.

Collins, M. D. (1985). Isoprenoid quinone analysis in classification and identification. In Chemical Methods in Bacterial Systematics, pp. 267-287. Edited by M. Goodfellow \& D. E. Minnikin. London: Academic Press.

Ezaki, T., Hashimoto, Y. \& Yabuuchi, E. (1989). Fluorometric deoxyribonucleic acid-deoxyribonucleic acid hybridization in microdilution wells as an alternative to membrane filter hybridization in which radioisotopes are used to determine genetic relatedness among bacterial strains. Int J Syst Bacteriol 39, 224-229.

Kwon, K. K., Lee, H.-S., Yang, S. H. \& Kim, S.-J. (2005). Kordiimonas gwangyangensis gen. nov., sp. nov., a marine bacterium isolated from marine sediments that forms a distinct phyletic lineage (Kordiimonadales ord. nov.) in the $\alpha$-Proteobacteria. Int J Syst Evol Microbiol 55, 2033-2037.

Marmur, J. (1961). A procedure for the isolation of deoxyribonucleic acid from microorganisms. J Mol Biol 3, 208-218.

Nichols, C. M., Bowman, J. P. \& Guezennec, J. (2005). Olleya marilimosa gen. nov., sp. nov., an exopolysaccharide-producing marine bacterium from the family Flavobacteriaceae, isolated from the Southern Ocean. Int J Syst Evol Microbiol 55, 1557-1561.

Sasser, M. (1990). Identification of bacteria by gas chromatography of cellular fatty acids, MIDI Technical Note 101. Newark, DE: MIDI Inc.

Sohn, J. H., Kwon, K. K., Kang, J.-H., Jung, H.-B. \& Kim, S.-J. (2004). Novosphingobium pentaromativorans sp. nov., a high-molecular-mass polycyclic aromatic hydrocarbon-degrading bacterium isolated from estuarine sediment. Int J Syst Evol Microbiol 54, 1483-1487.

Stackebrandt, E. \& Liesack, W. (1993). Nucleic acids and classification. In Handbook of New Bacterial Systematics, pp. 152-189. Edited by M. Goodfellow \& A. G. O’Donnell. London: Academic Press.

Wayne, L. G., Brenner, D. J., Colwell, R. R., Grimont, P. A. D., Kandler, O., Krichevsky, M. I., Moore, L. H., Moore, W. E. C., Murray, R. G. E. \& other authors (1987). International Committee on Systematic Bacteriology. Report of the ad hoc committee on reconciliation of approaches to bacterial systematics. Int J Syst Bacteriol 37, 463-464. 